\title{
Effect of New Auxin Herbicide Formulations on Control of Herbicide Resistant Weeds and on Microbial Activities in the Rhizosphere
}

\author{
Vijay K. Nandula*, Heather L. Tyler \\ Crop Production Systems Research Unit, U.S. Department of Agriculture-Agricultural Research Service, Stoneville, MS, USA \\ Email: *vijay.nandula@ars.usda.gov
}

How to cite this paper: Nandula, V.K. and Tyler, H.L. (2016) Effect of New Auxin Herbicide Formulations on Control of Herbicide Resistant Weeds and on Microbial Activities in the Rhizosphere. American Journal of Plant Sciences, 7, 2429-2439. http://dx.doi.org/10.4236/ajps.2016.717212

Received: September 22, 2016

Accepted: December 10, 2016

Published: December 13, 2016

Copyright $\odot 2016$ by authors and Scientific Research Publishing Inc. This work is licensed under the Creative Commons Attribution International License (CC BY 4.0).

http://creativecommons.org/licenses/by/4.0/

\section{(c) (i) Open Access}

\begin{abstract}
Widespread distribution of glyphosate-resistant weeds in soybean-growing areas across Mississippi has economically affected soybean planting and follow-up crop management operations. New multiple herbicide-resistant crop (including soybean) technologies with associated formulations will soon be commercialized. The objectives of this research were to determine the efficacy of new 2,4-D + glyphosate and dicamba formulations on herbicide resistant weeds, and to determine the impact of the new 2,4-D + glyphosate formulation on microbial communities in the soybean rhizosphere involved in nutrient cycling. New 2,4-D + glyphosate and dicamba formulations registered for use on 2,4-D and dicamba-resistant soybean, respectively, adequately controlled glyphosate resistant and susceptible pigweeds (Palmer amaranth and tall waterhemp) and common ragweed. The 2,4-D + glyphosate formulation did not significantly impact soil microbial activities linked to nutrient cycling in the soybean rhizosphere. These results indicate these new 2,4-D + glyphosate and dicamba formulations can be effective in controlling glyphosate resistant and other herbicide resistant weeds while not having adverse effects on the activities of beneficial soil microorganisms.
\end{abstract}

\section{Keywords}

2,4-D, Dicamba, Glyphosate, Resistance, Soil Microbiology, Soybean

\section{Introduction}

Initial efforts in the development of herbicide resistant crops resulted in the release of bromoxynil-resistant cotton in 1995 and canola in 2000, however, these were discontinued because bromoxynil is not a broad-spectrum herbicide [1]. The real turning 
point occurred in 1996-1997 with the commercial release of glyphosate-resistant (GR) canola (Brassica napus L.), soybean (Glycine max L. Merr.), and cotton (Gossypium hirsutum L.). Additional GR crops, alfalfa (Medicago sativa L.), corn (Zea mays L.), and sugarbeet (Beta vulgaris L.), were released to growers between 1998 and 2007. Glufosinate-resistant canola, released as early as in 1995, was not as widely adopted as GR canola. Glufosinate-resistant cotton was commercially made available in 2004, but was inferior in yield as compared to GR cotton. A new generation of GR cotton was developed in 2006 that had enhanced tolerance to glyphosate while at the same time allowed in-season glyphosate applications during the reproductive phase of the crop. New GR and glufosinate-resistant soybean germplasm was released in 2009. Glufosinate-resistant corn was commercialized for the first time in 1997 and was combined with GR corn varieties as a "double stacked trait" in the mid-2000s. This allowed control of a broader spectrum of weeds with the two unique modes of herbicide action [1].

An unfortunate consequence of commercialization of GR crops was the evolution of resistance to glyphosate in weed populations. The agrochemical industry, seed companies, and related entities have invested substantial resources in development of the next generation of herbicide resistant crops that have stacked multiple herbicide resistance traits. The aim of these efforts has been to diversify the growers' crop portfolio, as well as combat weed resistance by providing cropping technologies that allow application of more than one mode of action herbicides. These new technologies include the following: cotton (gyphosate + glufosinate + dicamba; glyphosate + glufosinate $+2,4-\mathrm{D}$ ), corn (glyphosate + glufosinate $+2,4$-D; glyphosate + dicamba; glyphosate + acetolactate synthase inhibitors (ALS) inhibitors), and soybean (glyphosate + glufosinate + dicamba; glyphosate + glufosinate + 2,4-D; glyphosate + 4-hydroxyphenylpyruvate dioxygenase (HPPD) inhibitors; glyphosate + glufosinate + HPPD inhibitors) [1]. Due to stringent regulatory/environmental monitoring and approval requirements, some of these technologies may never be commercialized. For example, a new mechanism of resistance to glyphosate was developed [2] and stacked with a high resistance trait from a different mechanism of action of herbicides, but was withdrawn a year or two from commercialization. Some of the technologies involving dicamba and 2,4-D resistance also have associated formulations specifically developed for application with these new stacked technologies [1]. Such formulations include 2,4-D choline formulation with glyphosate (Enlist $\mathrm{Duo}^{\oplus}$ ) from Dow AgroSciences and dicamba formulation (Engenia ${ }^{\oplus}$ ) from BASF.

Several resistant weed populations exist in Mississippi and neighboring states, some of which have multiple resistances (to more than one herbicide mode of action), cross resistance (to herbicides from different chemical families but similar modes of action), multiple mechanisms of resistance, or metabolism based resistance (endowing ability to detoxify more than one herbicide mode of action) [3]. Information on the efficacy of the above herbicide formulations on glyphosate resistant and other herbicide resistant weed populations infesting soybean growing areas of Mississippi is lacking.

Herbicides, such as glyphosate, applied to plants can be released into soil through 
root exudates [4] [5], or via direct contact, and after cultivation and rain events. These herbicides can have an impact on soil microorganisms that play an important role in plant nutrient availability by facilitating nutrient cycling and serving as the source of nodule forming rhizobia that provide fixed nitrogen to soybeans. Glyphosate application can alter microbial community composition [6] [7], and from a nutrient cycling perspective, it can have an inhibitory effect on phosphatase activity in soils [8] [9] and the activity of nitrogenase in some bacteria [10]. While the effects of glyphosate on soil microbial communities appear to be only minor and transient [6] [7] [11] [12], the combined application of multiple herbicides may have a greater impact.

Very little is known about how other herbicides influence soil microorganisms under field conditions. Dicamba and 2,4-D can be used as carbon sources by certain bacteria [13] [14], but these herbicides can have toxic and inhibitory effects on other bacteria [15] [16] [17] [18] [19]. There are also indications that these herbicides could have a direct impact on microbially mediated nutrient cycling. For example, dicamba has been shown to have an inhibitory effect on nitrogenase in the lab [16] and 2,4-D application can inhibit the activities of microbially secreted exoenzymes in soils linked to P and C cycling, including phosphatase [20] [21] and beta-glucosidase [20]. As such, application of these herbicides have the potential to cause shifts in the community composition and activity of bacteria in soil. However, many of these studies were carried out under laboratory conditions, or using toxic levels of herbicides above those used in the field. With the upcoming introduction of crops stacked with tolerances to both glyphosate and dicamba or 2,4-D, it is important to investigate the cumulative effect of these herbicides on the activity of soil microbial communities under agriculturally relevant conditions, since herbicides applied in combination might have a greater impact on soil microorganisms than when applied alone.

Therefore, the objectives of this research were to determine efficacy of new 2,4-D + glyphosate and dicamba formulations on selected herbicide resistant weeds, and to determine the impact of 2,4-D choline formulation on soybean rhizosphere microbial activities involved in nutrient cycling in two soil textures.

\section{Materials and Methods}

\subsection{Seed Sources, Germination, Planting, Growth, and Herbicide Treatment Conditions}

GR (biotypes GR1, GR2, GR3) and glyphosate-susceptible (GS) Palmer amaranth (Amaranthus palmeri S. Wats.), GR and GS tall waterhemp (Amaranthus tuberculatus Moq. Sauer), GR and GS common ragweed (Ambrosia artemisiifolia L.) seed was obtained from the USDA-ARS weed seed repository in Stoneville, MS. In the summer-fall of 2015, seeds of Palmer amaranth and tall waterhemp were planted at $1-1.5 \mathrm{~cm}$ depth in $10-\mathrm{cm}$ by $10-\mathrm{cm}$ by $10-\mathrm{cm}$ plastic pots containing a commercial potting mix (MetroMix 360, Sun Gro Horticulture, Bellevue, WA, USA), watered, and placed in a greenhouse $\left(25^{\circ} \mathrm{C}\right.$ day and $20^{\circ} \mathrm{C}$ night, 14 -h photoperiod under natural sunlight conditions supplemented with high pressure sodium lights providing $400 \mathrm{mmol} / \mathrm{m}^{2} / \mathrm{s}$ light inten- 
sity). Common ragweed seeds were planted and watered as above and incubated for a week at $2^{\circ} \mathrm{C}-8^{\circ} \mathrm{C}$ and then kept in the greenhouse as before. Two weeks after emergence, weed seedlings were transplanted into $6-\mathrm{cm}$ by $6-\mathrm{cm}$ by $6-\mathrm{cm}$ pots containing the potting mix. Plants were fertilized once with a nutrient solution (Miracle-Gro, The Scotts Company LLC, Marysville, OH, USA) containing $200 \mathrm{mg} / \mathrm{L}$ each of $\mathrm{N}, \mathrm{P}_{2} \mathrm{O}_{5}$, and $\mathrm{K}_{2} \mathrm{O}$ one week after transplanting and sub-irrigated as needed, thereafter. All herbicide treatments were applied with a backpack sprayer equipped with $8002 \mathrm{E}$ nozzles (Spraying Systems Co., Wheaton, IL, USA) delivering $140 \mathrm{~L} / \mathrm{ha}$ at $280 \mathrm{kPa}$ to weed and crop (soybean, growing procedure described below) plants. At the time of herbicide treatment with 2,4-D + glyphosate, Palmer amaranth and tall waterhemp plants were $\leq 12.5$ $\mathrm{cm}$ and $\geq 25 \mathrm{~cm}$ in height; with dicamba, Palmer amaranth and tall waterhemp plants were $\geq 25 \mathrm{~cm}$ in height. Common ragweed plants were $10-15 \mathrm{~cm}$ in height with both 2,4-D + glyphosate and dicamba. Soybean plants were at the two-three trifoliate stage when treated with 2,4-D + glyphosate or glyphosate alone. 2,4-D + glyphosate (choline + dimethylammonium salt, Enlist Duo, Dow AgroSciences, Indianopolis, IN, USA) was applied at a rate of $1.06 \mathrm{~kg}$ ae $/ \mathrm{ha}+1.13 \mathrm{~kg}$ ae/ha to both weed and soybean plants. In addition, a separate group of soybean plants were treated with glyphosate (potassium salt, Roundup WeatherMAX, Monsanto Co., St. Louis, MO, USA) alone at $1.13 \mathrm{~kg} / \mathrm{ha}$. Dicamba (N,N-Bis (3-aminopropyl) methylamine (BAPMA) salt, Engenia, BASF, RTP, NC) was applied to weeds at $0.7 \mathrm{~kg}$ ae/ha. Herbicide efficacy treatments are summarized in Table 1. Percent control [visible estimate of injury on a scale of 0 (no injury) to 100 (plant death)] and mortality were recorded for weeds 3 weeks after treatment (WAT).

2,4-D + glyphosate resistant soybean plants (variety GC16146889, provided by Dow AgroSciences), were grown in sandy loam and silty clay loam soils. Both soil types were collected from sites in Stoneville, MS, ground to disrupt clumps, and passed through a 1 $\mathrm{cm}$ sieve to remove debris. Pots $(15.2 \mathrm{~cm}$ diameter and depth) were set up containing either sandy loam (45 pots) or clay loam (45 pots) soil. Soybean seeds were soaked in water at room temperature overnight before planting to stimulate imbibition and germination. Soybeans were planted at a rate of 10 seeds per pot, and covered with a 1:1 sand:soil mixture to a depth of $2.5 \mathrm{~cm}$. Pots were placed in a greenhouse, watered every two to three days as needed, and maintained under $28^{\circ} \mathrm{C}$ day, $22^{\circ} \mathrm{C}$ night conditions

Table 1. Summary of treatments used in the herbicide efficacy study.

\begin{tabular}{ccccc}
\hline Weed species & Population & Height $(\mathrm{cm})$ & Herbicide & $\begin{array}{c}\text { Herbicide rate } \\
\text { (kg ae/ha) }\end{array}$ \\
\hline Palmer amaranth & GR1, GR2, GR3, GS & $\leq 12.5, \geq 25$ & $2,4-\mathrm{D}+$ glyphosate & $1.06+1.13$ \\
& GR1, GR2, GR3, GS & $\geq 25$ & Dicamba & 0.7 \\
Tall waterhemp & GR, GS & $\leq 12.5, \geq 25$ & $2,4-\mathrm{D}+$ glyphosate & $1.06+1.13$ \\
& GR, GS & $\geq 25$ & Dicamba & 0.7 \\
Common ragweed & GR, GS & $10-15$ & $2,4-\mathrm{D}+$ glyphosate & $1.06+1.13$ \\
& GR, GS & $10-15$ & Dicamba & 0.7 \\
\hline
\end{tabular}


with a 13-hr photoperiod of natural light supplemented with artificial lighting as described above. Nineteen days after planting, seedlings were thinned down to four per pot, selecting to keep plants that were of similar size and developmental stage (early second trifoliate stage). Soybeans were sprayed 27 days after planting as described above. Plant treatments included no herbicide application, glyphosate alone, and 2,4-D + glyphosate.

\subsection{Soybean Rhizosphere Analysis}

Rhizosphere soil was collected from plants at 1, 3, 7, 14, and 30 days post application (DPA) of herbicide treatment. Rhizosphere analysis treatments are summarized in Table 2. At each time point, the soil-root mass from three replicate pots for each soil type and treatment was removed, gently broken up to dislodge bulk soil, and shaken to remove all but the soil tightly adhered to roots (rhizosphere soil). Approximately $5 \mathrm{~g}$ of root + rhizosphere was transferred to a $50 \mathrm{~mL}$ centrifuge tube and kept on ice until all pots were sampled. $50 \mathrm{mM}$ acetate buffer ( $\mathrm{pH} \mathrm{5)}$ was added to each tube until the root sample was submerged (approximately 20 - $30 \mathrm{~mL}$ ). Each tube was vortexed for $1 \mathrm{~min}$ and then placed in a sonicating water bath for $1 \mathrm{~min}$ in order to dislodge rhizophere soil from the roots. Roots were removed from the tubes using sterile forceps. The resulting rhizosphere soil slurries were assayed for the activities of phosphatase, $\beta$-glucosidase, and $\mathrm{N}$-acetylglucosaminidase (NAGase) in 96-well plate format using p-nitrophenol (pNP)-linked assays as described previously [22], with some modifications. Briefly, for each enzyme assayed, $150 \mu \mathrm{L}$ of rhizosphere slurry was pipetted into six wells in a deep well plate, vortexing vigorously between wells. Next, $150 \mu \mathrm{L}$ of pNPlinked substrate solution was added to four replicate samples wells for the enzyme reactions. The remaining two sample wells on each block served as sample blanks and contained only $150 \mu \mathrm{L}$ rhizosphere slurry and $150 \mu \mathrm{L} 50 \mathrm{mM}$ acetate buffer. Substrate solutions were prepared as previously described [22]. Assays were incubated at $25^{\circ} \mathrm{C}$ with shaking (150 RPM). Incubation times varied by enzyme: $30 \mathrm{~min}$ for phosphatase, $1.5 \mathrm{hr}$ for $\beta$-glucosidase, $2.5 \mathrm{hr}$ for NAGase, and $16 \mathrm{hr}$ for cellobiohydrolase. Following incubation, deep well plates were centrifuged at $3220 \times \mathrm{g}$ for $5 \mathrm{~min}$. $150 \mu \mathrm{L}$ of supernatant was withdrawn from each well and transferred to a 96-well plate containing $150 \mu$ Lof $0.067 \mathrm{M} \mathrm{NaOH}$ stop reagent. The absorbance of each plate was read at $410 \mathrm{~nm}$. Ab

Table 2. Summary of treatments used in the soybean rhizosphere study.

\begin{tabular}{cccc}
\hline Soil type & $\begin{array}{c}\text { Rhizosphere sampling time } \\
\text { (days post treatment) }\end{array}$ & Herbicide & $\begin{array}{c}\text { Herbicide rate } \\
\text { (kg ae/ha) }\end{array}$ \\
\hline Sandy loam & $1,3,7,14,30$ & None & 0 \\
Silty clay loam & $1,3,7,14,30$ & 2,4 -D + glyphosate & $1.06+1.13$ \\
& $1,3,7,14,30$ & Glyphosate & 1.13 \\
& $1,3,7,14,30$ & None & 0 \\
& $1,3,7,14,30$ & 2,4 -D + glyphosate & $1.06+1.13$ \\
\hline
\end{tabular}


sorbance of soil slurry blank wells was subtracted from reaction wells and compared to a standard curve of known pNP concentrations to determine the amount of substrate consumed. Dry weight determinations for the amount rhizosphere soil per reaction were performed in triplicate, pipetting $150 \mu \mathrm{L}$ of slurry from each sample into pre-weighed aluminum tins, incubating overnight at $105^{\circ} \mathrm{C}$, and weighing the next morning. Weight of the pan was subtracted from the dry weight to get the weight per reaction.

Enzyme activities were calculated as the nmole of substrate consumed per $\mathrm{g}$ dry weight per hour. Analysis of Variance (ANOVA) was performed in JMP version 11.2.0 (SAS Institute Inc., Carey, NC) to determine if there were any significant differences between herbicide treatments in the two soil textures, with an $\alpha$ of 0.05 .

\section{Results and Discussion}

\subsection{Herbicide Efficacy}

All pigweed plants (GR and GS Palmer amaranth and tall waterhemp) were completely controlled when treated with 2,4-D + glyphosate at $\leq 12.5 \mathrm{~cm}$ in height (Table 3 ). When pigweed plants were treated with 2,4-D + glyphosate at a height of $\geq 25 \mathrm{~cm}$ two GR Palmer amaranth populations, GR2 and GR3, were completely controlled, but $13 \%$ of plants from a third GR Palmer amaranth population, GR1, survived, though severely injured. The GR waterhemp population was also severely injured, but $7 \%$ of treated

Table 3. Response of glyphosate-resistant (GR) weed species to 2,4-D + glyphosate and dicamba. Survival rating is based on presence of an actively growing apical or lateral meristem. Percent control rating is based on visible injury to plants ${ }^{\mathrm{a}}$.

\begin{tabular}{cccccccc}
\hline Weed species & Population & $\begin{array}{c}\text { Height } \\
(\mathrm{cm})\end{array}$ & Herbicide & $\begin{array}{c}\text { \#Plants } \\
\text { treated }\end{array}$ & $\begin{array}{c}\text { \#Plants } \\
\text { survived }\end{array}$ & $\begin{array}{c}\text { Surviv- } \\
\text { al } \%\end{array}$ & \% Control \\
\hline Palmer amaranth & GR1 & $\leq 12.5$ & $2,4-\mathrm{D}+$ glyphosate & 15 & 0 & 0 & 100 \\
Palmer amaranth & GR2 & $\leq 12.5$ & $2,4-\mathrm{D}+$ glyphosate & 15 & 0 & 0 & 100 \\
Palmer amaranth & GR3 & $\leq 12.5$ & $2,4-\mathrm{D}+$ glyphosate & 15 & 0 & 0 & 100 \\
Tall waterhemp & GR & $\leq 12.5$ & $2,4-\mathrm{D}+$ glyphosate & 15 & 0 & 0 & 100 \\
Palmer amaranth & GR1 & $\geq 25$ & $2,4-\mathrm{D}+$ glyphosate & 15 & 2 & 13 & 90 \\
Palmer amaranth & GR2 & $\geq 25$ & $2,4-\mathrm{D}+$ glyphosate & 15 & 0 & 0 & 100 \\
Palmer amaranth & GR3 & $\geq 25$ & $2,4-\mathrm{D}+$ glyphosate & 15 & 0 & 0 & 100 \\
Tall waterhemp & GR & $\geq 25$ & $2,4-\mathrm{D}+$ glyphosate & 15 & 1 & 7 & 95 \\
Common ragweed & GR & $10-15$ & $2,4-\mathrm{D}+$ glyphosate & 15 & 0 & 0 & 100 \\
Palmer amaranth & GR1 & $\geq 25$ & Dicamba & 15 & 0 & 0 & 100 \\
Palmer amaranth & GR2 & $\geq 25$ & Dicamba & 15 & 0 & 0 & 100 \\
Palmer amaranth & GR3 & 250 & Dicamba & 15 & 15 & 100 & 80 \\
Tall waterhemp & GR & $\geq 25$ & Dicamba & 15 & 12 & 80 & 40 \\
Common ragweed & GR & $10-15$ & Dicamba & 15 & 0 & 0 & 98 \\
\hline
\end{tabular}

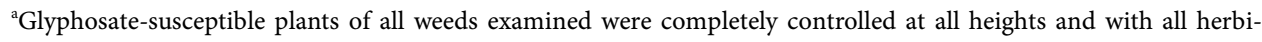
cides. 
plants survived (Table 3).

Dicamba was applied only to $\geq 25$-cm pigweeds. As with 2,4-D + glyphosate, two GR Palmer amaranth populations, GR1 and GR2, were completely controlled, but a third GR population, GR3, had 100\% survival (Table 3). Similarly, a GR waterhemp population had $80 \%$ survival 3 WAT. GR pigweed populations, Palmer amaranth and waterhemp, which survived dicamba at $25-\mathrm{cm}$ height at the time of treatment, did not put out new healthy growth even by 8 WAT. Plants remained injured or began to senesce without any evidence of new growth (data not shown). GR and GS common ragweed, 4- to 6-inches in height at the time of treatment, were completely controlled by both 2,4-D + glyphosate and dicamba.

\subsection{Soybean Rhizosphere Analysis}

Due to lack of availability of dicamba resistant soybean, only the new 2,4-D + glyphosate formulation was assessed for its potential impact on the soybean rhizosphere. 2,4-D + glyphosate did not significantly alter the activities of NAGase or cellobiohydrolase in the rhizosphere of soybean plants grown in either sandy loam (Figure 1(c) and Figure 1(d)) or clay loam (Figure 2(c) and Figure 2(d)) soils at any of the time points measured. Phosphatase activities also did not differ significantly between treatments in either soil texture for most of the experiment (Figure 1(a) and Figure 2(a)). One exception was observed 14 days after herbicide application in sandy loam soils, when phosphatase activity in the rhizosphere of 2,4-D + glyphosate treated plants was significantly lower than untreated plants $(\mathrm{p}=0.022)$. However, this effect was transient and phosphatase activity had recovered to non-treated levels by the end of the experiment.

$\beta$-glucosidase activity in the rhizosphere was largely unaffected by herbicide application in either soil texture (Figure $1(\mathrm{~b})$ and Figure $2(\mathrm{~b})$ ). The only statistically significant difference occurred 7 days after application in clay loam soils, when $\beta$-glucosidase activity was $17 \%$ higher in $2,4-\mathrm{D}+$ glyphosate than in untreated plants $(\mathrm{p}=0.042)$. However, this difference was small compared to the variability between rhizosphere samples at other time points and not likely to be biologically relevant.

Overall, microbial activities varied greatly among samples. However, there was no consistent impact of herbicide application on microbial activities between sandy loam and clay loam soil textures. Most differences in rhizosphere activity observed between herbicide treatments were transient in nature and not statistically significant, an observation that is consistent with previous studies looking at the effects of glyphosate [23] and 2,4-D [20] on glucosidase and phosphatase activities in soil. Previous studies reporting greater impacts on microbial activities used substantially higher dosages than the field rates used in the current study [9] [21]. Given the current results, it appears that the combined application of both glyphosate and 2,4-D do not significantly influence soil activities in the soybean rhizosphere.

In summary, with no new herbicide modes of action on the horizon, multiple herbicide resistant crops with resistance to 2,4-D or dicamba and one or more other herbi- 


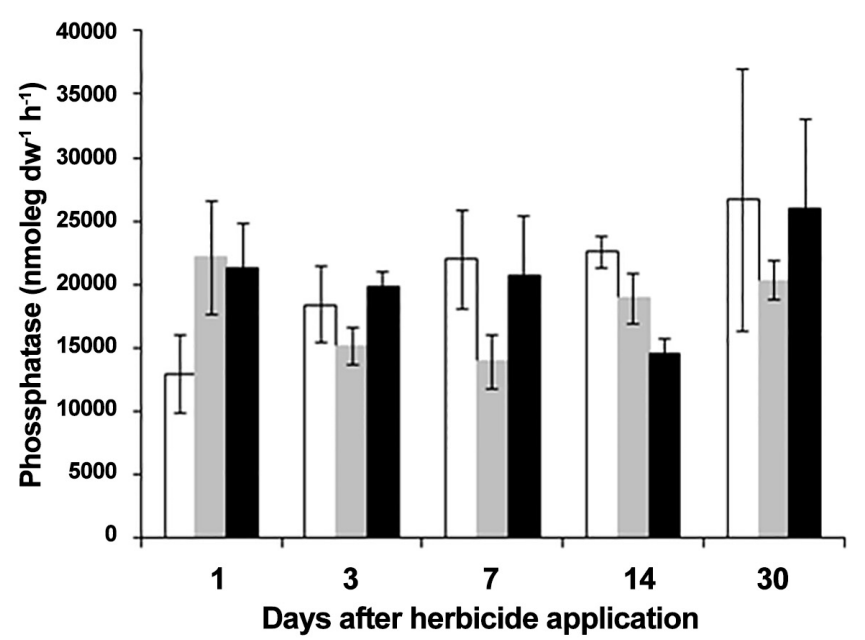

(a)

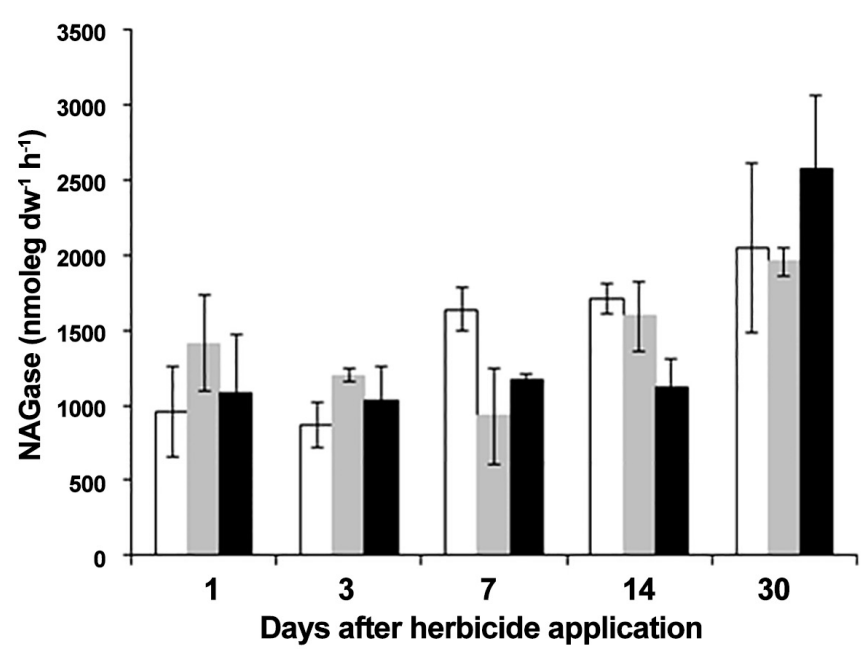

(c)

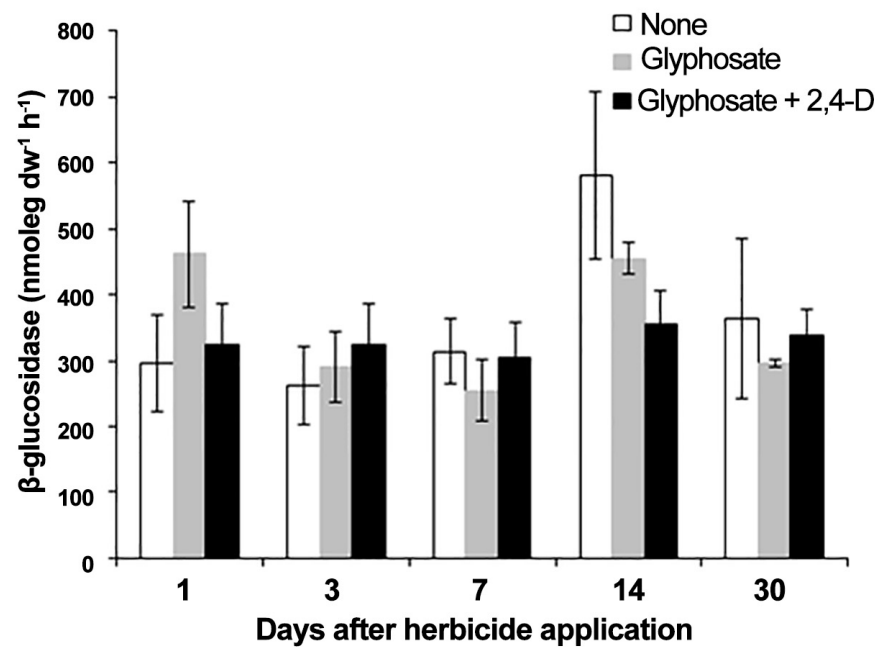

(b)

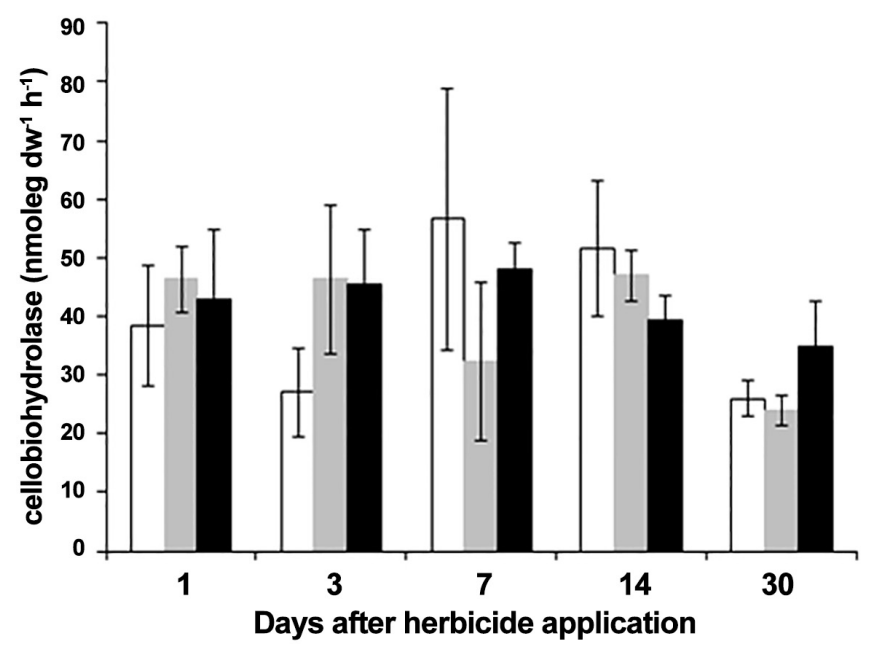

(d)

Figure 1. Mean \pm standard error of phosphatase (a), $\beta$-glucosidase (b), N-acetylglucosaminase (NAGase) (c), and cellobiohydrolase (d) activities in the rhizosphere of untreated, glyphosate treated, or glyphosate $+2,4-\mathrm{D}$ treated soybean plants grown in a sandy loam soil. The data from each treatment represents three replicates, with each replicate being composed of the pooled rhizosphere soil from four plants, for a total of 12 soybean rhizospheres collected per treatment and time point.

cides can be effective tools in combating herbicide resistant and non herbicide resistant weed populations. Although, several troublesome weed species such as Palmer amaranth and tall water hemp are resistant to glyphosate, the new formulations of 2,4-D and dicamba labeled for multiple herbicide resistant crops tested in this research demonstrated their effectiveness in controlling large sized weed plants. This tool could be effectively used for post harvest weed control. An additional benefit of these formulations is the lack of adverse effects on soil microbial flora associated with crops such as soybean. Soil microbial flora plays a tremendously important role in nitrogen fixation and nutrient cycling essential for adequate crop growth and development. 


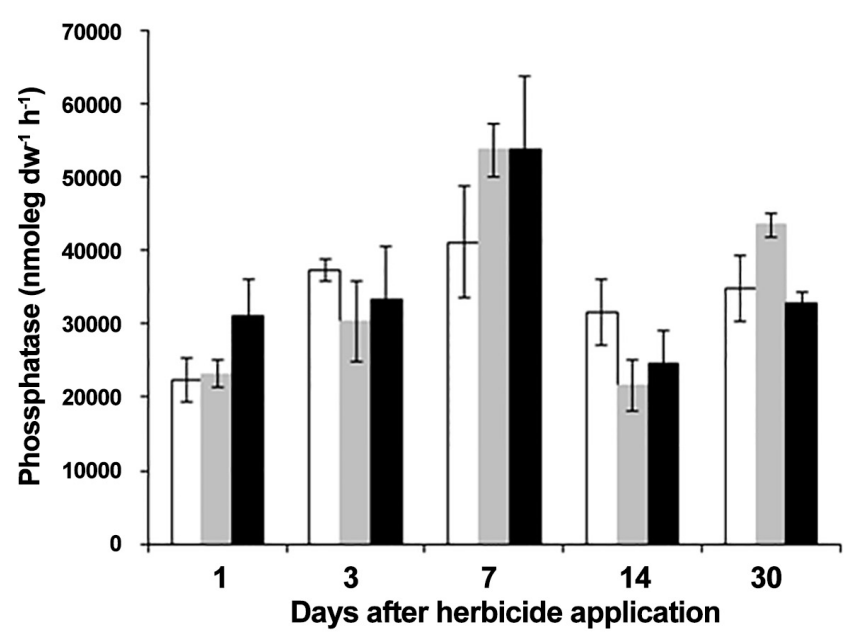

(a)

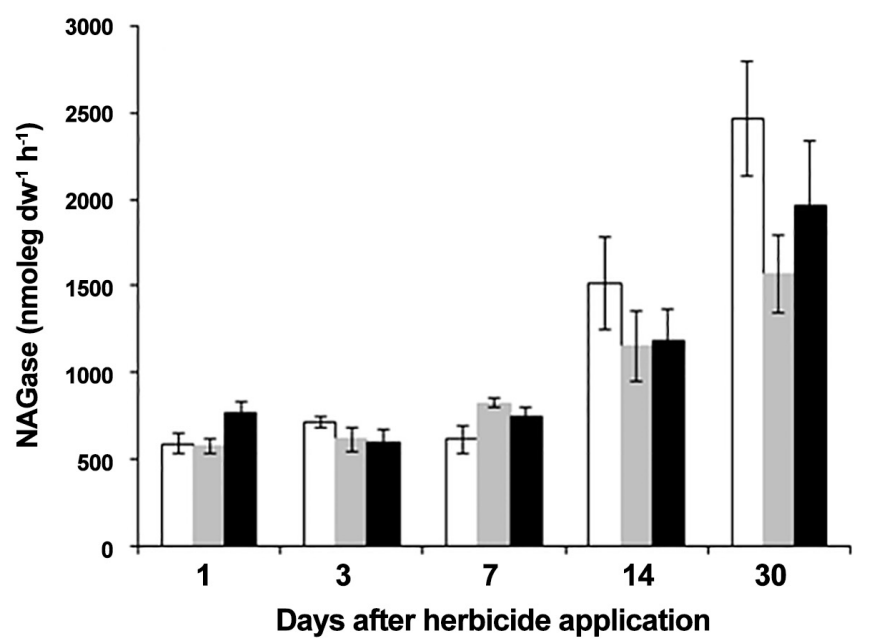

(c)

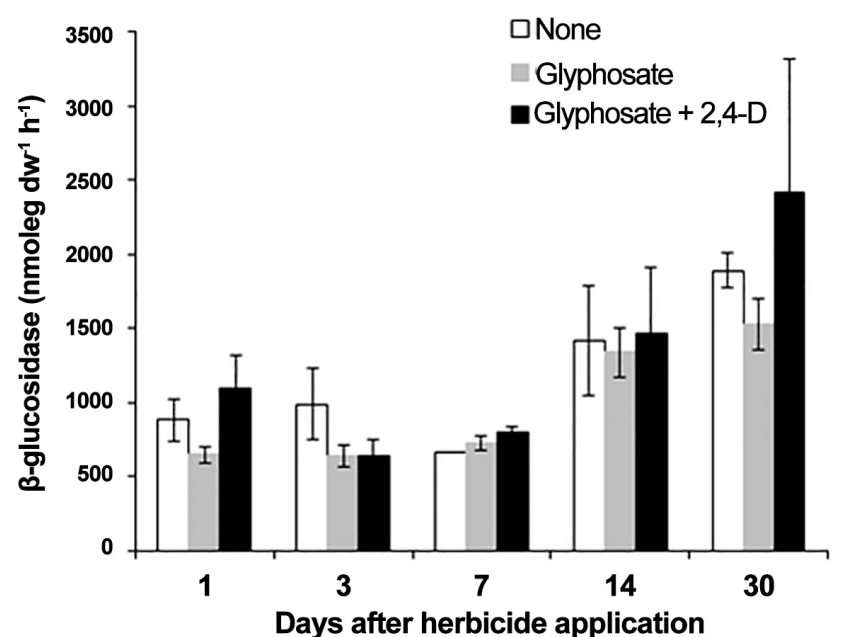

(b)

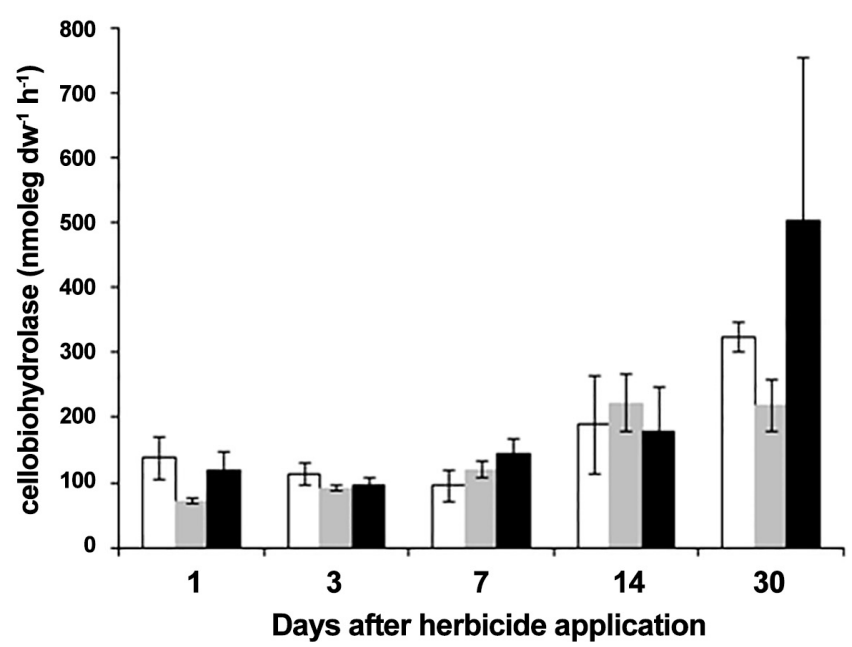

(d)

Figure 2. Mean \pm standard error of phosphatase (a), $\beta$-glucosidase (b), N-acetylglucosaminase (NAGase) (c), and cellobiohydrolase (d) activities in the rhizosphere of untreated, glyphosate treated, or glyphosate $+2,4-\mathrm{D}$ treated soybean plants grown in a silty clay loam soil. The data from each treatment represents three replicates, with each replicate being composed of the pooled rhizosphere soil from four plants, for a total of 12 soybean rhizospheres collected per treatment and time point.

\section{Conclusion}

The above results clearly indicate that the new 2,4-D + glyphosate and dicamba formulations registered for use on 2,4-D and dicamba-resistant soybean, respectively, provide a very viable alternative for controlling GR as well as wild types of troublesome pigweeds such as Palmer amaranth and tall waterhemp, and other broadleaf weeds such as common ragweed. Furthermore, the new 2,4-D + glyphosate formulation does not significantly impact the activities of soil microorganisms linked to nutrient cycling in the soybean rhizosphere.

\section{Acknowledgements}

Funding for this research from the Mississippi Soybean Promotion Board is gratefully 
acknowledged.

\section{References}

[1] Reddy, K.N. and Nandula, V.K. (2014) Herbicide Resistant Crops: History, Development, and Current Technologies. Indian Journal of Agronomy, 57, 1-7.

[2] Castle, L.A., Siehl, D.L., Gorton, R., Ratten, P.A., Chen, Y.H., Bertain, S., Cho, H.J., Duck, N., Wong, J., Liu, D. and Lassner, M.W. (2004) Discovery and Directed Evolution of a Glyphosate Tolerance Gene. Science, 304, 1151-1154. https://doi.org/10.1126/science.1096770

[3] Heap, "International Survey of Herbicide Resistant Weeds," 2016. http://www.weedscience.org/Summary/home.aspx

[4] Coupland, D. and Caseley, J.C. (1979) Presence of ${ }^{14} \mathrm{C}$ Activity in Root Exudates and Guttation Fluid from Agropyron repens Treated with ${ }^{14} \mathrm{C}$-Labelled Glyphosate. New Phytologist, 83, 17-22. https://doi.org/10.1111/j.1469-8137.1979.tb00721.x

[5] Kremer, R.J., Means, N.E. and Kim, S. (2005) Glyphosate Affects Soybean Root Exudation and Rhizosphere Micro-Organisms. International Journal of Environmental Analytical Chemistry, 85, 1165-1174. https://doi.org/10.1080/03067310500273146

[6] Arango, L., Buddrus-Schiemann, K., Opelt, K., Lueders, T., Haesler, F., Schmid, M., Ernst, D. and Hartmann, A. (2014) Effects of Glyphosate on the Bacterial Community Associated with Roots of Transgenic Roundup Ready ${ }^{\circ}$ Soybean. European Journal of Soil Biology, 63, 41-48. https://doi.org/10.1016/j.ejsobi.2014.05.005

[7] Barriuso, J., Marin, S. and Mellado, R.P. (2011) Potential Accumulative Effect of the Herbicide Glyphosate on Glyphosate-Tolerant Maize Rhizobacterial Communities over a ThreeYear Cultivation Period. PLOS ONE, 6, e27558.

https://doi.org/10.1371/journal.pone.0027558

[8] Sannino, F. and Gianfreda, L. (2001) Pesticide Influence on Soil Enzymatic Activities. Chemosphere, 45, 417-425. https://doi.org/10.1016/S0045-6535(01)00045-5

[9] Yu, Y., Zhang, H. and Zhou, Q. (2011) Using Soil Available P and Activities of Soil Dehydrogenase and Phosphatase as Indicators for Biodegradation of Organophosphorus Pesticide Methamidophos and Glyphosate. Soil and Sediment Contamination, 20, 688-701.

https://doi.org/10.1080/15320383.2011.594110

[10] Haahtela, K., Kilpi, S. and Kari, K. (1988) Effects of Phenoxy Acid Herbicides and Glyphosate on Nitrogenase Activity (Acetylene Reduction) in Root-Associated Azospirillum, Enterobacter and Klebsiella. FEMS Microbiology Letters, 53, 123-127. https://doi.org/10.1111/j.1574-6968.1988.tb02655.x

[11] Weaver, M.A., Krutz, L.J., Zablotowicz, R.M. and Reddy, K.N. (2007) Effects of Glyphosate on Soil Microbial Communities and Its Mineralization in a Mississippi Soil. Pest Management Science, 63, 388-393. https://doi.org/10.1002/ps.1351

[12] Zablotowicz, R.M. and Reddy, K.N. (2007) Nitrogenase Activity, Nitrogen Content, and Yield Responses to Glyphosate in Glyphosate-Resistant Soybean. Crop Protection, 26, 370376. https://doi.org/10.1016/j.cropro.2005.05.013

[13] Fournier, J.C. (1980) Enumeration of the Soil Microorganisms Able to Degrade 2,4-D by Metabolism or Co-Metabolism. Chemosphere, 9, 169-174.

https://doi.org/10.1016/0045-6535(80)90089-2

[14] Krueger, J.P., Butz, R.G., Atallah, Y.H. and Cork, D.J. (1989) Isolation and Identification of Microorganisms for the Degradation of Dicamba. Journal of Agricultural and Food Chemi- 
stry, 37, 534-538. https://doi.org/10.1021/jf00086a057

[15] Balagué, C., Stürtz, N., Duffard, R. and De Duffard, A.M.E. (2001) Effect of 2,4-Dichlorophenoxyacetic Acid Herbicide Escherichia coli Growth, Chemical, Composition, and Cellular Envelope. Environmental Toxicology, 16, 43-53. https://doi.org/10.1002/1522-7278(2001)16:1<43::AID-TOX50>3.0.CO;2-R

[16] Gonzalez-Lopez, J., Moreno, J., De la Rubia, T., Martinez-Toledo, M.V. and Ramos-Cormenzana, A. (1984) Toxicity of Dicamba (2-Methoxy-3,6-Dichlorobenzoic Acid) to Azotobacter vinelandii. Folia Microbiologica, 29, 127-130. https://doi.org/10.1007/BF02872928

[17] Oleszczuk, P., Jośko, I., Futa, B., Pasieczna-Patkowska, S., Pałys, E. and Kraska. P. (2014) Effect of Pesticides on Microorganisms, Enzymatic Activity and Plant in Biochar-Amended Soil. Geoderma, 214-215, 10-18. https://doi.org/10.1016/j.geoderma.2013.10.010

[18] Rivarola, V., Fabra, A., Mori, G. and Balegno, H. (1992) In Vitro Protein Synthesis Is Affected by the Herbicide 2,4-Dichlorophenoxyacetic Acid in Azospirillum brasilense. Toxicology, 73, 71-79. https://doi.org/10.1016/0300-483X(92)90171-A

[19] Zabaloy, M.C. and Gómez, M.A. (2005) Diversity of Rhizobia Isolated from an Agricultural Soil in Argentina Based on Carbon Utilization and Effects of Herbicides on Growth. Biology and Fertility of Soils, 42, 83-88. https://doi.org/10.1007/s00374-005-0012-2

[20] Bécaert, V., Samson, R. and Deschênes, L. (2006) Effect of 2,4-D Contamination on Soil Functional Stability Evaluated Using the Relative Soil Stability Index (RSSI). Chemosphere, 64, 1713-1721. https://doi.org/10.1016/j.chemosphere.2006.01.008

[21] Gupta, D. and Joshi, N. (2009) Changes in Microbial Biomass and Phosphatase Activity Exposed to 2,4-D and Glyphosate. Journal of Environmental Research and Development, 3, 663-669.

[22] Jackson, C.R., Tyler, H.L. and Millar, J.J. (2013) Determination of Microbial Extracellular Enzyme Activity in Waters, Soils, and Sediments Using High Throughput Microplate Assays. Journal of Visualized Experiments, 80, e50399. https://doi.org/10.3791/50399

[23] Nakatani, A.S., et al. (2014) Effects of the Glyphosate-Resistance Gene and of Herbicides Applied to the Soybean Crop on Soil Microbial Biomass and Enzymes. Field Crops Research, 162, 20-29. https://doi.org/10.1016/j.fcr.2014.03.010

\section{Submit or recommend next manuscript to SCIRP and we will provide best service for you:}

Accepting pre-submission inquiries through Email, Facebook, LinkedIn, Twitter, etc.

A wide selection of journals (inclusive of 9 subjects, more than 200 journals)

Providing 24-hour high-quality service

User-friendly online submission system

Fair and swift peer-review system

Efficient typesetting and proofreading procedure

Display of the result of downloads and visits, as well as the number of cited articles

Maximum dissemination of your research work

Submit your manuscript at: http://papersubmission.scirp.org/

Or contact ajps@scirp.org 